
Not for reproduction, distribution or commercial use.

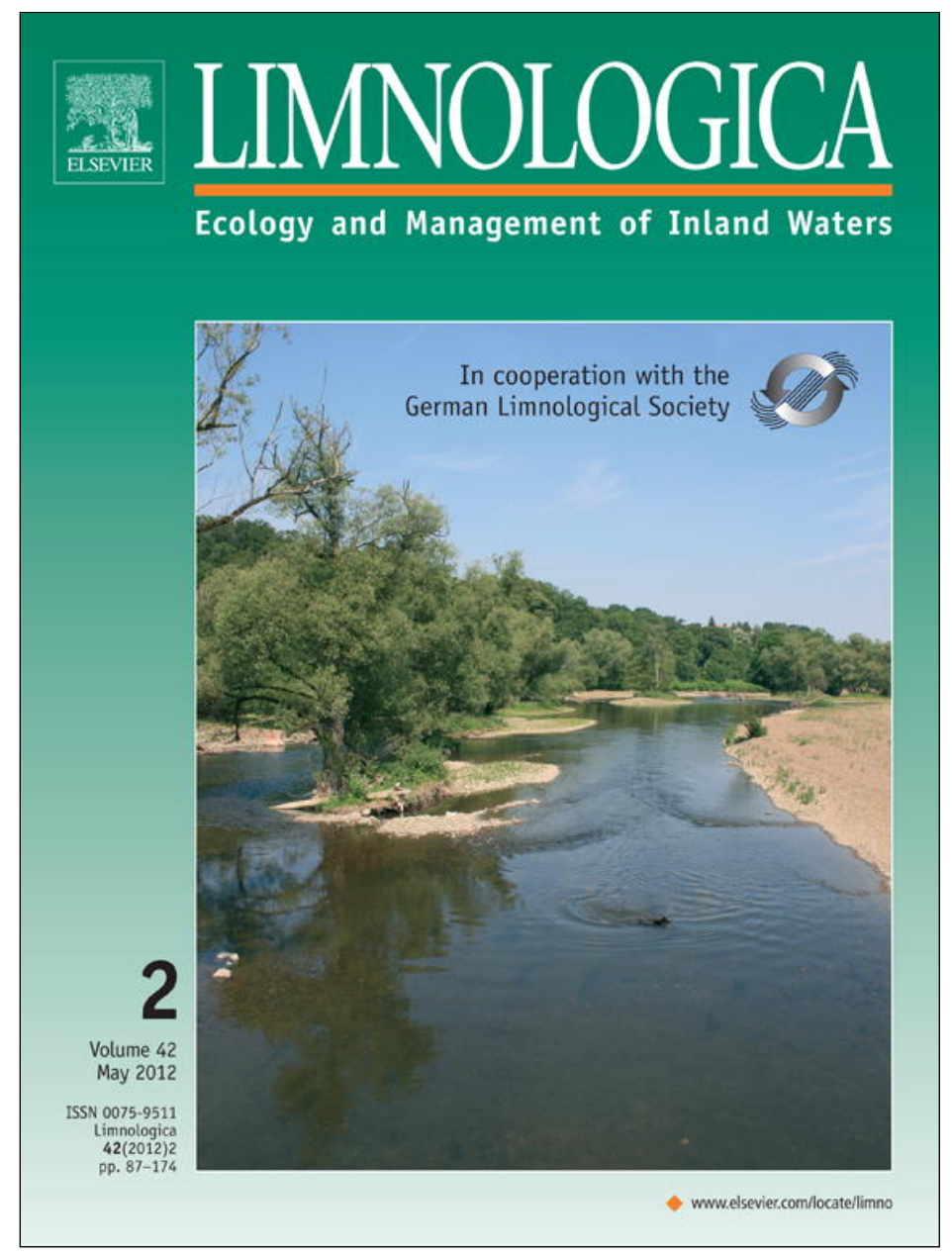

This article appeared in a journal published by Elsevier. The attached copy is furnished to the author for internal non-commercial research and education use, including for instruction at the authors institution and sharing with colleagues.

Other uses, including reproduction and distribution, or selling or licensing copies, or posting to personal, institutional or third party websites are prohibited.

In most cases authors are permitted to post their version of the article (e.g. in Word or Tex form) to their personal website or institutional repository. Authors requiring further information regarding Elsevier's archiving and manuscript policies are encouraged to visit:

http://www.elsevier.com/copyright 


\title{
Measuring ecological change of aquatic macrophytes in Mediterranean rivers
}

\author{
Ian Dodkins*, Francisca Aguiar, Rui Rivaes, António Albuquerque, \\ Patricia Rodríguez-González, Maria Teresa Ferreira \\ Forest Research Centre, Technical University of Lisbon, Faculty of Agronomy, Tapada da Ajuda, 1349-017 Lisboa, Portugal
}

\section{A R T I C L E I N F O}

\section{Article history:}

Received 18 October 2010

Received in revised form 18 August 2011

Accepted 2 September 2011

\section{Keywords:}

Water Framework Directive

Biological assessment

Detrended Correspondence Analysis

Reciprocal Averaging

Aquatic macrophytes

Weighted Averaging

\begin{abstract}
A B S T R A C T
A metric was developed for assessing anthropogenic impacts on aquatic macrophyte ecology by scoring macrophyte species along the main gradient of community change. A measure of ecological quality was then calculated by Weighted Averaging (WA) of these species scores at a monitoring site, and comparison to a reference condition score. This metric was used to illustrate the difficulties of developing aquatic macrophyte indices based on indicator species in Mediterranean rivers. The response of the metric to a nutrient gradient was examined within two different river typologies: the national typology designed for the Water Framework Directive and a typology that segregates the environmental variables to produce maximum species similarity within a river type. Both typologies showed the strong north-south climatic divide in Portugal, with southern rivers having long periods without rainfall and often without flowing water in the summer. Overall, the metric responded well to nutrient impacts however it performed poorly in some southern lowland river types. This was thought to be due to low numbers of aquatic macrophytes in temporary rivers. Non-aquatic species that establish in the river channel of temporary rivers may have to be included in indices to improve performance. Also, simple Weighted Averaging (WA) metrics may be insensitive to abundance changes and loss of rarer indicators in lowland Mediterranean rivers. More sophisticated methods of using WA are suggested, as well as further research into developing assessment methods specific to the character of Mediterranean rivers.
\end{abstract}

(C) 2011 Elsevier GmbH. All rights reserved.

\section{Introduction}

Under the Water Framework Directive (WFD) (Council of the European Communities, 2000) European Member States are required to develop methods of ecological assessment that classify rivers and lakes into five ecological quality classes based on their flora and fauna (WFD, Article 8). The purpose of this study was to illustrate the difficulties of developing WFD compliant macrophyte metrics in Mediterranean regions. A metric based on community similarity was used as an example.

Many countries are considered to have Mediterranean climates including Italy, Croatia, Greece, western Turkey, northern Morocco and southern Iberia. Such climates have a mixture of perennial (permanent flow) and intermittent (flowless in summer) rivers. The Mediterranean climate typically has strong seasonal and annual variability in rainfall, with mild winters and dry summers. For example, Barcelona in northern Iberia has a median of 22 Dry Days Since Last Rain (DDSLR), whereas Loule in southern Iberia has a median of 83 DDSLR (Reiser and Kutiel, 2010).

\footnotetext{
* Corresponding author. Tel.: +351 965658 552; fax: +351239823603.

E-mail address: ian.dodkins@gmail.com (I. Dodkins).
}

Fewer aquatic macrophyte species are found in the drier rivers of southern Iberia than in the north. For example, in northern Portugal 104 aquatic macrophyte species were found in routine surveys, with a mean of 13.5 species per site, whereas in southern Portugal there were only 94 species, with a mean of 12.7 species per site (Dodkins et al., 2011). In the Iberian interior many rivers are dry for a large part of the year, and may have no truly aquatic vascular macrophytes or bryophytes. Since metrics which use WA of species scores are detrimentally affected by low species numbers (Dodkins et al., 2011) ecological assessment strategies may have to be adapted for countries with Mediterranean climates.

The history of aquatic macrophyte metric development is less extensive than for invertebrates (Hawkes, 1998; Pantle and Buck, 1955) or diatoms (De Pauw and Vanhooren, 1983; Persoone and De Pauw, 1979), and the metrics which have been developed have originated in temperate climates (Haury et al., 2006; Holmes et al., 1999; Melzer, 1999). Whilst invertebrates and diatoms have been shown to be good indicators of organic enrichment (Armitage et al., 1983) and acidification (Lenoir and Coste, 1996), doubts have arisen over the reliability of macrophyte metrics in showing a true response to nutrient impacts within the WFD due to the over-riding effects of other limiting factors such as light and small scale habitat structure (Demars and Edwards, 2009; Dodkins and Rippey, 2008). Despite this, macrophytes are vitally important ecological 
components of rivers, providing food (Carpenter and Lodge, 1986; Marshall and Westlake, 1978) and habitat structure (Cheruvelil et al., 2000; Collier et al., 1999; Den Hartog, 1982), and altering water chemistry (Carpenter and Lodge, 1986).

In Iberia the performance of different metrics has generally been poor. Two metrics which score species along a trophic gradient, the Mean Trophic Rank (MTR) (Holmes et al., 1999) and the Índice de Macrófitos (Suarez et al., 2005), were applied in Portugal and Spain, respectively. MTR had low correlations with nutrient impacts except in highly eutrophic and oligotrophic rivers (Szoszkiewicz et al., 2006), and the Índice de Macrófitos had an $r^{2}$ value of only 0.165 with phosphate concentration (Suarez et al., 2005). Two alternative approaches, using measures of community similarity based on the River InVertebrate Prediction And Classification System (RIVPACS) (Wright, 1995) and the BEnthic Assessment of SedimenT (BEAST) method (Reynoldson et al., 1995) were also assessed in Portugal (Aguiar et al., 2011). Both had low rank correlations with nutrient gradients; equivalent to an $r^{2}$ of $\leq 0.16$. A third approach using functional groups, the Riparian Vegetation Index (RVI), was also applied in Portugal (Ferreira et al., 2005). This performed better, with an $r^{2}$ of 0.31 against a combined pressure gradient in northern Portuguese rivers, and $r^{2}$ of 0.56 in Southern Portuguese rivers. However, the index could not be used within the WFD as it included terrestrial species from the riparian zone.

These three types of metrics (gradient, community change and functional group metrics) have different advantages and disadvantages. Metrics calibrated along a pressure gradient are likely to reduce the effect of natural variation on a metric score compared to metrics which assess community change, although other limiting factors (Demars and Edwards, 2009) or small scale physical habitat variation (Dawson et al., 1999) can still have a large influence on these metrics. Also, insufficient quality or quantity of chemical data for calibration often limits the development of gradient metrics. Assessing metric performance using linear regression against a nutrient impact may favour the gradient metrics, whereas community change metrics respond to multiple pressures simultaneously and therefore may not give good correlations with single specific pressure gradients. However, linear regression, and increasingly rank regression, help to distinguish the metric response to human impacts from that due to natural variation and it is still the most frequently used method to confirm a response to nutrient impacts in the WFD.

To illustrate the difficulties of developing metrics for Mediterranean regions, a simple metric was chosen which is not limited by the quality of the physico-chemical data and combines aspects of both gradient and community change metrics.

\section{Methods}

\section{Data collection}

A total of 378 river sites (Fig. 1) were surveyed throughout nine geographically located river types specified in the Portuguese national river typology (Aguiar et al., 2008; INAG, 2008b). Large river types, that require a different sampling methodology, were not included. 262 of the sites were considered to have impacts that varied in severity and type. The remaining 116 sites belong to the Portuguese national network of reference conditions, previously selected using digital databases from the Water Institute (INAG IP), the Portuguese Water Resources Information System, expert judgment and field campaigns. They were considered category A or B waters for multiple human uses since they met the criteria for good chemical quality for nitrate, nitrite, phosphates, ammonia, $\mathrm{pH}, \mathrm{BOD}_{5}$ and COD. There was no obvious alteration to channel morphology and no major abstractions or flow alterations. There were low levels of urbanisation and industrial activity in the catchment and all expected physical habitats were present at the sites, with mostly intact riparian zones. These reference sites are considered to be either the "least disturbed" or "best available" sites in Portugal sensu Stoddard et al. (2006).

Conductivity and $\mathrm{pH}$ were measured at the sites with the WTW (Wissenschaftlich-Technische Werkstätten) field probes. Water samples were collected for the analysis of other water quality determinands using standard methods (Bartram and Ballance, 1996; Clesceri et al., 1999), i.e. Alkalinity (titration with sulphuric acid), nitrate (cadmium reduction), total Kjeldahl nitrogen (mineralization and titration), Biological Oxygen Demand (dissolved oxygen measured with a probe after 5 days of incubation), and orthophosphate and total phosphorus (using ammonium molybdate). The morphological alterations of the river channel and the riparian zone were determined on site, using the River Habitat Survey (Raven et al., 1998) whilst hydrological alterations, erosional sediment deposits and land use areas were obtained from national GIS databases available at http://www.inag.pt/snirh. Connectivity was evaluated based on the number of relevant barriers, such as dams and weirs, along the river segment.

A macrophyte survey was done over a $100 \mathrm{~m}$ length at each of the 378 river channel sites, including both inner banks and the main channel, and including channels that had only sub-surface water. The fieldwork was performed in the Spring and early Summer of 2004 and 2005 with sampling methods following the European standard (CEN, 2003), which has been incorporated into a standard Portuguese sampling method (INAG, 2008a). Although it is unlikely that species with an early vegetation period were missed, abundances may be lower than the peak for species with later vegetation periods.

The initial survey included hydrophytes (truly aquatic species), helophytes (emergent species), hygrophytes (tolerant to submersion but normally rooted in wet soil) and terrestrial species. Although common macro-algae (e.g. Cladophora spp., Lemanea spp., Lyngbia spp., Vaucheria spp.) were sometimes identified, the only genus consistently recorded was Lemanea and therefore other macro-algae genera were either too rare or inconsistent in their abundance to be included in the data.

Surveyors waded upstream within the channel in a zig-zag manner, re-wading downstream to ensure that all the species were recorded and to confirm species abundance (measured as percentage cover). If channel access was hazardous, surveying was done by walking along the banks, or by boat. Vascular plants were identified in the field and liverworts and bryophytes from the channel were collected for later identification.

\section{Selection of indicator species}

The European Standards for aquatic macrophyte monitoring (CEN, 2003) includes only hydrophytes and helophytes. However, Mediterranean temporary rivers often have hygrophytes and even terrestrial species within the river channel that may be indicative of hydrological regime and prior nutrient status (Dodkins et al., 2011). Terrestrial species were not included in this study, retaining only species with an Aquaticity of five or less (Appendix A) within the dataset, i.e. freshwater hydrophytes, helophytes, and hygrophytes.

\section{Calculating species scores}

A metric based on scoring species was used since it can reduce the effect of natural variation and is an approach being used extensively within Europe (Birk, 2011), e.g. in the UK and Ireland (Willby et al., 2009), France, Belgium, Italy and Croatia (Haury et al., 2006), 

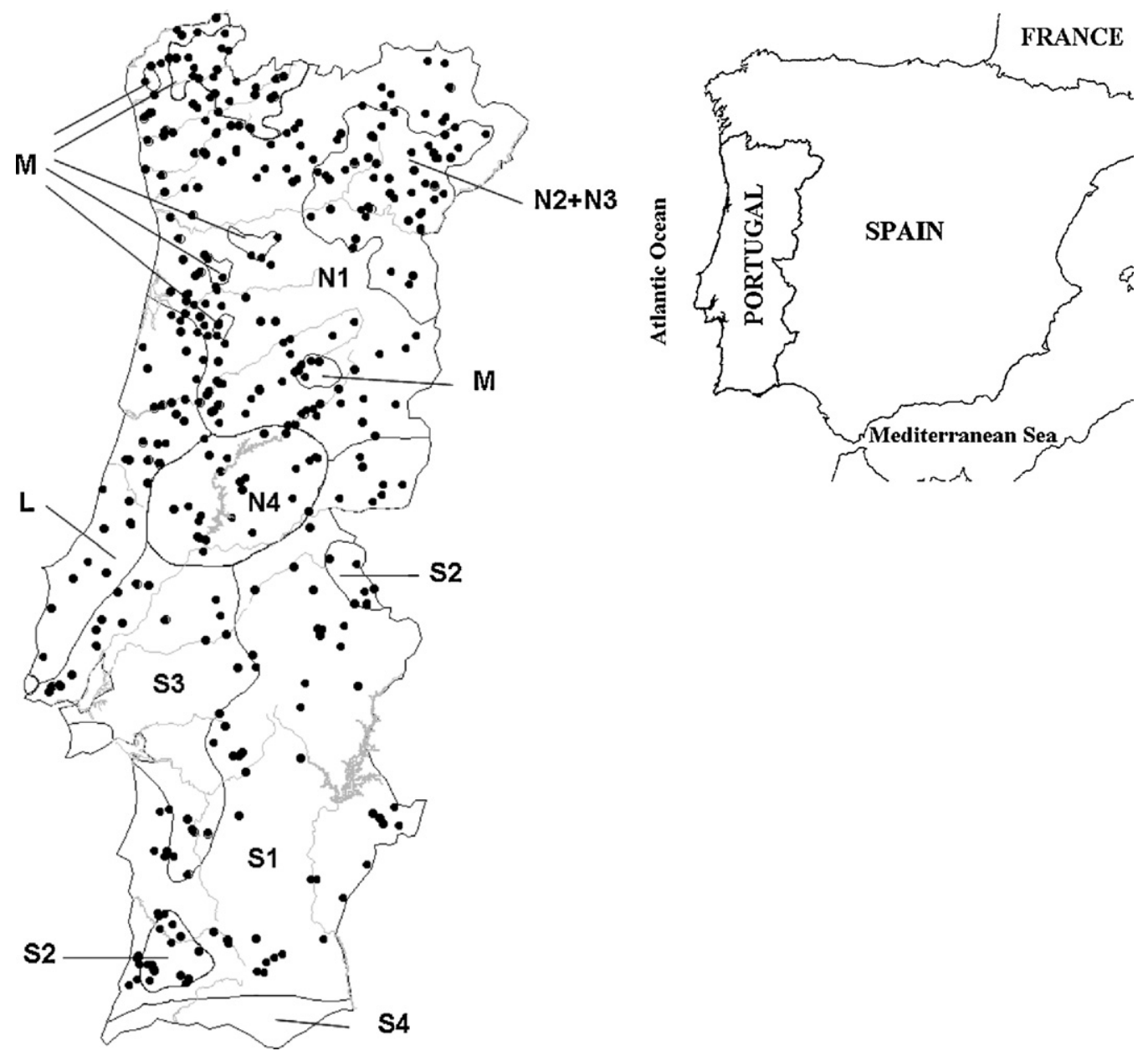

Fig. 1. Location of the 378 surveyed sites within Portugal and their river type within the national typology (see Table 1).

Austria (Pall and Mayerhofer, 2008) and Poland (Szoszkiewicz et al., 2008). However, the calibration of species against a measured pressure gradient was avoided as the results would depend upon the pressure gradient chosen, and the physico-chemical data available was only semi-quantitative, i.e. hydrological and hydromorphological data was categorical, $79 \%$ of sites had nitrate values at or below the $\operatorname{LoD}\left(1.2 \mathrm{mg} \mathrm{L}^{-1}\right), 85 \%$ of sites had total phosphorus concentrations at or below the $\operatorname{LoD}\left(0.2 \mathrm{mg} \mathrm{L}^{-1}\right)$ and $92 \%$ of sites had ammonia concentrations below the $\operatorname{LoD}\left(0.4 \mathrm{mg} \mathrm{L}^{-1}\right)$.

A metric similar to that of Lavoie et al. (2006) was used, whereby species are scored along the first axis in a Correspondence Analysis (CA) (Benzérci, 1973). CA is an ordination method that scores species based on the main gradient in species change. Therefore species with similar scores are more likely to occur together within the same environment, i.e. the score is a quantitative measure of the type of community the species belongs to. Contrary to Lavoie et al. (2006) we preferred Detrended Correspondence Analysis (DCA) over CA since it ensures unit within-sample variance for the calculation of species scores and prevents the ends of the species score gradient being compressed (Hill and Gauch, 1980). DCA was applied to the aquatic macrophyte species data at the 378 sites using CANOCO 4.5 (ter Braak and Smilauer, 2002). The percentage cover data was square root transformed prior to analysis, since root transformation is appropriate for bounded data (Sokal and Rohlf, 1995), and a square root transformation resulted in higher Eigenvalues than either no or forth root transformation. The species scores along the first ordination axis were rescaled to integers between 1 and 10 .
Validation of the metric

The biological metric scores were calculated for each of the 378 sites. The biological metric score for a monitoring site is the mean of the species scores that occur at that site, weighted by their cover, i.e. the Weighted Averaging (WA) equation (ter Braak and Looman, 1986):

$S=\frac{\sum_{i=1}^{n} C_{i} Q_{i}}{\sum_{i=1}^{n} C_{i}}$

where $S=$ site score, $n=$ number of species, $C_{i}=$ cover scale value of species $i$ (see below), and $Q_{i}=$ score of species $i$.

The cover scale values used to weight the mean were: 0 (for $0 \%$ macrophyte cover relative to the channel area), 1 ( $\leq 1 \%$ cover), 2 ( $\leq 5 \%$ cover), 5 ( $\leq 33 \%$ cover) and 6 ( $>33$ cover). These cover weighting values and categories were chosen since it is easy to estimate a third of channel cover, and the weighting increased the correlation when tested against a pressure gradient (described below).

Nutrient enrichment is usually considered the most important human impact within Europe, and is the main pressure considered when testing the current indices within the WFD. Principal Component Analysis (PCA) was used to combine nitrate, total nitrogen and impermeable surface area (urbanisation in the catchment) parameters into a single pressure gradient. The parameters were chosen as they were all strongly correlated with nitrate; commonly considered a nutrient variable to which aquatic macrophytes have a strong response (Carbiener et al., 1990; Dodkins et al., 2005a). Nitrate 
Table 1

River types within the national typology.

\begin{tabular}{llrl}
\hline River type & Description & No. of sites & $\begin{array}{c}\text { Reference and impacted sites } \\
\text { significantly different? }\end{array}$ \\
\hline L & Littoral central streams (occidental coastal streams) & 6 & $\begin{array}{l}r^{2} \text {-Value, when metric } \\
\text { regressed against impact }\end{array}$ \\
M & Small-sized mountainous streams of North & 8 & Y \\
N1 & Small and medium sized streams of North & 13 & Y \\
N2 & Medium and large-sized streams of Alto Douro & 9 & 0.442 \\
N3 & Small-sized streams of Alto Douro & 37 & 0.444 \\
N4 & Transition North-South & 17 & 0.356 \\
S1 & Small and medium sized streams of South & 11 & 0.497 \\
S2 & Small-sized mountainous streams of South & 23 & 0.333 \\
S3 & Sedimentary deposits of Tagus and Sado rivers & 0.143 \\
\end{tabular}

could not be used alone as many of the values were below the LoD, however this was not the case for total nitrogen and impermeable surface area measurements. The first axis of a PCA using these three variables was used to produce a site impact score representing the nutrient pressure at each site. The scaling of the biological metric score was not expected to have a linear relationship with nutrient concentration; therefore the PCA pressure gradient values were converted to ranks prior to regression against the biological metric.

\section{Assessment of metric performance - the national typology}

The WFD's Ecological Quality Ratio (EQR) was used to quantify the amount of ecological deterioration due to anthropogenic pressures. This must be calculated as a ratio between the metric score at the monitoring site, and that at reference condition. A high score (around 1) represents high ecological quality whilst a low score (towards zero) represents bad quality. The reference condition is specific to a river type since unimpacted macrophyte communities naturally differ between river types. The Portuguese national typology (Fig. 1, Table 1) was developed based on the abiotic variables suggested in the WFD (Aguiar et al., 2008) and divided into geographic regions. The median biological metric score of the reference sites within each of the nine river types was calculated to produce the reference condition metric score for each river type. ANOVA and Tukey tests (Fowler et al., 1998) were done to see if there was a significant difference between the mean metric score for reference sites and the mean metric score for impacted sites, within each river type.

\section{Assessment of metric performance - The LINKTREE typology}

An alternative typology was developed by grouping reference sites that have maximum species similarity, and finding which environmental parameter, and where along the environmental gradient, these groups are best separated. This can be achieved using LINKTREE within the Primer v.6 software (Clarke and Gorley, 2006). The result is a discrete river typology based on environmental variables that maximally separates the aquatic macrophyte communities found at reference condition. The only environmental variables used to produce the typology were those considered important in structuring the species distribution, and which were not pressure gradients, i.e. latitude, $\mathrm{pH}$, alkalinity, discharge (based on rainfall), width, depth, altitude, distance from source, catchment area, and whether the river was temporary or permanent. As with the national typology, the reference condition for each river type was calculated as the mean biological metric score of the reference sites within the river type. The EQR was then calculated for the 378 sites. ANOVA and Tukey tests were done to see if there was a significant difference between the mean reference and impacted site scores within each river type.

\section{Species typical of Northern, Southern and Mountainous river types}

Since Northern, Southern and Mountainous regions were delimited within both typologies, the species typical of these regions were compared. The frequency of different species at reference and impacted condition was calculated within these river types, as well as the number of species that occurred at reference but not impacted sites and vice versa.

\section{Results}

Table 2 shows the range and median of physico-chemical, physical and landscape scale data for all river sites. Table 3 shows the median values of nutrient determinands and land-use for only the reference sites. The values are presented for each river type in the LINKTREE typology.

In the species data, only $12 \%$ of the original species were helophytes and hydrophytes, the other species being terrestrial or hygrophytes. 105 species (hydrophytes, helophytes and some hygrophytes) were chosen as indicators within the metric. The most commonly occurring of these were Oenanthe crocata (309 sites), Lythrum salicaria (223 sites), Polygonum hydropiper (212 sites) and Lycopus europaeus (208 sites). All these species have a low dependence on root submergence for survival. Conversely, species less commonly found were more strongly associated with constant submergence, e.g. Isoetes histrix, Elodea canadensis, and Callitriche obtusangula, each found at only three sites. Species occurring at less than three sites were not included in the analysis. Several common bryophytes were completely absent in the south: Fontinalis antipyretica, Fontinalis squamosa and Rhyncostegium riparioides. The invasive Arundo donax was found at 80 sites, whereas another invasive, Eichhornia crassipes (water hyacinth), was only found at 5 sites.

Table 2

Range and median values of the main parameters measured in this study.

\begin{tabular}{llll}
\hline Determinand & Minimum & Maximum & Median \\
\hline Water chemistry & & & \\
Conductivity $\left(\mu \mathrm{S} \mathrm{cm}^{-1}\right)$ & 9 & 1772 & 121 \\
$\mathrm{pH}$ & 5.0 & 9.1 & 7.3 \\
Alkalinity $\left(\mathrm{mg} \mathrm{HCO}_{3}{ }^{2-} \mathrm{L}^{-1}\right)$ & $<10$ & 442 & 31 \\
Nitrate $\left(\mathrm{mg} \mathrm{NO}_{3} \mathrm{~L}^{-1}\right)$ & $<1.2$ & 34.2 & 1.4 \\
Total nitrogen $\left(\mathrm{mg} \mathrm{N} \mathrm{L}^{-1}\right)$ & $<0.5$ & 16.4 & 1.4 \\
Orthophosphate $\left(\mathrm{mg} \mathrm{PO}_{4} \mathrm{~L}^{-1}\right)$ & $<0.13$ & 6.00 & $<0.13$ \\
Total phosphorous $\left(\mathrm{mg} \mathrm{P} \mathrm{L}^{-1}\right)$ & $<0.2$ & 2.0 & $<0.2$ \\
Physical & & & \\
HQA (habitat quality assessment) & 14 & 64 & 42 \\
HMS (habitat modification score) & 0 & 67 & 5 \\
Width (m) & 0.4 & 200.0 & 5.2 \\
Depth (m) & 0.0 & 3.0 & 0.3 \\
Distance from source (m) & 29 & 237,153 & 18025 \\
Discharge (mm rainfall) & 75 & 2200 & 350 \\
Landscape & & & \\
Altitude (m) & 3 & 1414 & 160 \\
Area (km $\left.{ }^{2}\right)$ & 1 & 5402 & 81 \\
\hline
\end{tabular}


Table 3

Environmental quality of reference sites within the LINKTREE typology shown as median values of chemical and landscape determinands. $(<)$ Indicates below the Limit of Detection (LoD).

\begin{tabular}{|c|c|c|c|c|c|c|c|c|c|c|}
\hline & LoD & & A & M & N1 & $\mathrm{N} 2$ & N3 & N4 & N5 & N6 \\
\hline Nitrate $\left(\mathrm{mg} \mathrm{NO}_{3} \mathrm{~L}^{-1}\right)$ & 1.2 & & $<$ & $<$ & $<$ & 2.5 & 1.3 & $<$ & $<$ & $<$ \\
\hline Ammonia $\left(\mathrm{mg} \mathrm{NH}_{4} \mathrm{~L}^{-1}\right)$ & 0.4 & & $<$ & $<$ & $<$ & $<$ & $<$ & $<$ & $<$ & $<$ \\
\hline Total nitrogen ( $\mathrm{mg} \mathrm{N} \mathrm{L}^{-1}$ ) & 0.5 & & $<$ & $<$ & $<$ & 1.66 & 1.30 & 1.29 & 2.00 & 2.37 \\
\hline Total phosphorous ( $\mathrm{mg} \mathrm{P} \mathrm{L}^{-1}$ ) & 0.2 & & $<$ & $<$ & $<$ & $<$ & $<$ & $<$ & $<$ & $<$ \\
\hline Orthophosphate ( $\mathrm{mg} \mathrm{PO}_{4} \mathrm{~L}^{-1}$ ) & 0.1 & & $<$ & $<$ & $<$ & $<$ & $<$ & $<$ & $<$ & $<$ \\
\hline Agriculture in catchment (\%) & - & & 1 & 1 & 1 & 15 & 15 & 24 & 31 & 20 \\
\hline Natural area in catchment (\%) & - & & 99 & 95 & 99 & 75 & 64 & 72 & 66 & 80 \\
\hline \multirow[t]{2}{*}{ Artificial surface in catchment (\%) } & - & & 0 & 0 & 0 & 5 & 0 & 0 & 1 & 0 \\
\hline & S1 & $\mathrm{S} 2$ & S3 & S4 & S5 & $\mathrm{T} 1$ & $\mathrm{~T} 2$ & T3 & $\mathrm{T} 4$ & T5 \\
\hline Nitrate $\left(\mathrm{mg} \mathrm{NO}_{3} \mathrm{~L}^{-1}\right)$ & $<$ & 5.8 & $<$ & $<$ & 1.6 & $<$ & $<$ & $<$ & 1.5 & $<$ \\
\hline Ammonia (mg NH $\left.\mathrm{L}_{4} \mathrm{~L}^{-1}\right)$ & $<$ & $<$ & $<$ & $<$ & $<$ & $<$ & $<$ & $<$ & $<$ & $<$ \\
\hline Total Nitrogen $\left(\mathrm{mg} \mathrm{N} \mathrm{L}^{-1}\right)$ & 1.07 & 2.25 & $<$ & $<$ & 2.27 & $<$ & $<$ & 0.59 & $<$ & 0.57 \\
\hline Total Phosphorous ( $\mathrm{mg} \mathrm{P} \mathrm{L}^{-1}$ ) & $<$ & $<$ & $<$ & $<$ & $<$ & $<$ & $<$ & $<$ & $<$ & $<$ \\
\hline Orthophosphate $\left(\mathrm{mg} \mathrm{PO}_{4} \mathrm{~L}^{-1}\right)$ & $<$ & $<$ & $<$ & $<$ & $<$ & $<$ & $<$ & $<$ & $<$ & $<$ \\
\hline Agriculture in catchment (\%) & 23 & 26 & 57 & 26 & 26 & 18 & 21 & 34 & 50 & 40 \\
\hline Natural area in catchment (\%) & 73 & 73 & 43 & 73 & 72 & 81 & 79 & 66 & 48 & 60 \\
\hline Artificial surface in catchment (\%) & 3 & 1 & 0 & 0 & 0 & 0 & 0 & 0 & 0 & 0 \\
\hline
\end{tabular}

\section{Calculating species scores}

Appendix B shows the species scores derived from the first axis of the DCA, rescaled between 1 and 10. Species with low scores are associated with high conductivity and nutrient enrichment, e.g. Potamogeton pusillus and E. canadensis have scores of 1 . Conversely, upland bryophytes and liverworts associated with low conductivities and low nutrient status had high scores, e.g. Jungermania spp. (score of 8), Scapania spp. (score of 9) and Philonotis fontana (score of 10).

Many of the species had similar scores to the Mean Trophic Rank (Holmes et al., 1999) score, i.e. these species differed by no more than one from MTR: Alisma lanceolatum, Alisma plantago-aquatica, Brachythecium rivulare, Brachythecium rutabulum, C. obtusangula, $F$. antipyretica, F. squamosa, Iris pseudochorus, Lemenea, Lemna gibba, L., Lemna minor, Potamogeton crispus, Potamogeton natans, Ranunculus peltatus, Ranunculus trichophyllus, Rhyncostegium ripariodes, Schoenoplectus lacustris, Sparganium erectum, Thamnobryum alopercus and Typha latifolia. This suggests a strong association of the scores with a trophic gradient. Notable deviations from this pattern were Callitriche hamulata (3) which scored much lower than in MTR (9), and many of the upland species which had lower scores than found in MTR, i.e. Amblystigium riparium (scored 5 in this metric compared to 1 in MTR), Eleogitan fluitans (6 cf. 10), Equisetum palustris (4 cf. 6), Hygrohypnum ochraceum (7 cf. 9), Juncus bulbosus (8 cf. 10) and Potamogeton polygonifolius (6 cf. 10). Also Chara fragilis, which tends to be associated with oligotrophic conditions (though it can have a broad ecological range), only scored 2 in this study. Phragmitis australis, despite being ubiquitous, was given a score of 1 . Many species from the MTR were either not recorded or recorded too rarely to be used as indicators, e.g. Nuphar lutea, Cinclidotis and Sagittaria sagittifolia.

\section{Validation of the metric}

A general nutrient gradient had to be derived from a composition of impacts since many of the values for nutrient determinands were below the limit of detection. The first axis in a PCA represented this combination of nitrate, nitrogen and impermeable surface area gradients. This axis had a Pearson's correlation coefficient of 0.911 with impermeable surface area, 0.698 with nitrate and 0.617 with total nitrogen. The PCA axis was then converted to a rank value, since the biological metric was not considered to have a linear relationship with nutrient status. This rank PCA axis had slightly lower correlations with the above determinands (0.806, 0.611 and 0.575 , respectively).

There was a high correlation (Pearson's correlation 0.776 , $r^{2}=0.602$ ) in the regression of the rank nutrient pressure gradient against the biological metric scores calculated at each site. Altering the cover values used to weight the mean species score had some effect, varying the $r^{2}$-value between 0.510 and 0.604 . However, regardless of the choice of weightings, it was evident that it was more useful to have low weights for the very low coverage species, and to rely predominantly on the scores of the higher abundance species. The final coverage classes were chosen as they were simple, made sense, and gave a good correlation with the impact. However, weighting based on percentage cover rather than dominance is likely to change the functioning of a metric. For example, in 26 streams the dominant species had less than $1 \%$ cover, whereas in 96 streams the dominant species had greater than 33\% cover. Using the percentage cover in rivers that have high natural variation in the area of available habitat between sites (e.g. due to area of photic zone) may make comparisons between reference and monitoring sites less accurate (Dodkins and Rippey, 2008).

The hydromorphological and hydrological variables had low correlations with the metric over the 378 sites, e.g. discharge category $\left(r^{2}=0.312\right)$, connectivity category $(0.179)$ and erosional sediment deposits category (0.166). Hydromorphological and hydrological variables were expected to have a strong correlation with species change (Dodkins et al., 2005a; Haury, 1996; Wilby et al., 1998), and the DCA metric should represent the main impacts on species. However, it is possible that the semi-quantitative (categorical) nature of the hydromorphological and hydrological data resulted in these low correlations rather than there being a poor metric response. Other important variables that the metric responded to are conductivity $\left(r^{2}=0.597\right)$, alkalinity $(0.355)$ and $\mathrm{pH}(0.335)$. The higher correlation with the nutrient pressure gradient rather than alkalinity suggests the metric is more responsive to nutrient changes than natural variability in alkalinity.

\section{Assessment of metric performance - the national typology}

The regression of the EQR against a pressure (nutrient) gradient within the national typology shows some correlation in most river types (Fig. 2). The metric represents the main gradient of community change, and not specifically nutrient enrichment, and therefore 

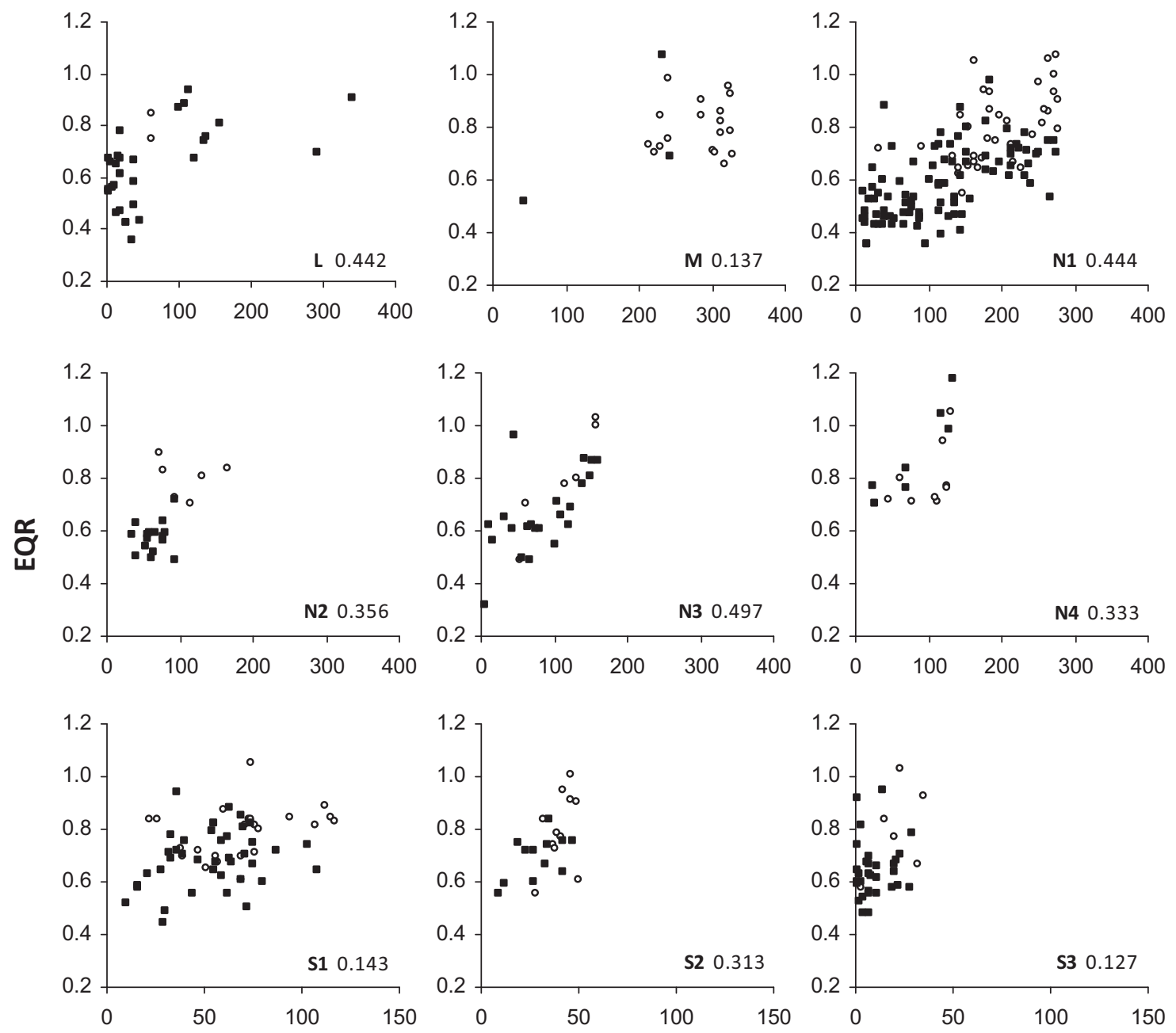

\section{Nutrient gradient from PCA (rank)}

Fig. 2. Ecological Quality Ratio (EQR) of sites surveyed within river types of the national typology, plotted against a nutrient gradient (constructed from the 1 st PCA axis of total nitrogen concentration, nitrate concentration, and impermeable surface area in the catchment). The $x$-axis is the rank nutrient gradient and the $y$-axis is the EQR value. The letter within each chart indicates the river type, and is followed by the $r^{2}$ value. Impacted sites are indicated as closed circles, reference sites as open circles.

it is surprising how good the correlation is within river type N3. The southern river types and mountainous river types have lower correlations with the nutrient gradient. In river type N3 it is likely that nutrient enrichment (rather than abstraction or hydromorphological impacts) is the main cause of impact, and thus there is a high correlation.

Even so, ANOVA and Tukey tests showed that only river types N1, N2 and S1 types had a significant difference $(P=0.05)$ between reference and impacted sites (Fig. 4). This may be because some of the impacts are not from nutrient enrichment, although on examination of Fig. 4 the overlap is large between reference conditions and impacted sites in most of the river types (but especially N4 and S2), suggesting few differences between many of the reference and impacted communities. The metric appears to perform poorly in river type $\mathrm{N} 4$, which has a higher mean metric value for impacted sites than for reference sites. Type N4 is a transition area between the northern and southern regions, therefore this erroneous result may be due to differences in the natural river vegetation rather than due to impacts. This river type may require further separation to produce more accurately defined river types. The southern rivers tend to have poor correlations between the nutrient gradient and the metric.

\section{Assessment of metric performance - the LINKTREE typology}

Eighteen river types were produced from the LINKTREE analysis (Table 4). LINKTREE produces a bifurcating tree based on the position along an environmental gradient that maximally separates (reference) sites based on species dissimilarity. The tree structure makes it simple to produce a key to classify sites into a river type (Appendix C). Divisions in the analysis were stopped if one of the resultant groups had less than five reference sites.

The LINKTREE typology shows good correlations in the lower alkalinity northern rivers (N2 and N3, Fig. 3a). Again, the acidic river type (A) has a low correlation with the nutrient gradient which is likely to be due to the small ecological response of macrophytes to nutrient enrichment within acidic rivers (Robach et al., 1996). Although some of the southern river types (S1, S3, S4) again have poor correlations with the nutrient gradient, type S5 and some temporary rivers (T3, T4) have a good correlation. Type S5 is deeper rivers (less likely to be dry) and types $\mathrm{T} 3$ and $\mathrm{T} 4$ are close to the river source, and therefore less likely to be affected by dry periods. Indeed, these sections of the river may not be dry at all, but just the upstream sections of larger river sections that are dry further down. 
Table 4

River types within the LINKTREE typology.

\begin{tabular}{|c|c|c|c|c|}
\hline River type & Description & No. of sites & $\begin{array}{l}\text { Reference and impacted sites } \\
\text { significantly different? }\end{array}$ & $\begin{array}{l}r^{2} \text {-Value, when metric } \\
\text { regressed against impact }\end{array}$ \\
\hline A & Mountainous rivers at very high altitude & 6 & $\mathrm{Y}$ & 0.090 \\
\hline M & Naturally very acidic areas & 8 & & 0.270 \\
\hline \multicolumn{5}{|c|}{ Northern rivers } \\
\hline N1 & Upland sites & 11 & $\mathrm{Y}$ & 0.327 \\
\hline N2 & Low alkalinity rivers of the far north & 17 & $\mathrm{Y}$ & 0.513 \\
\hline N3 & Low alkalinity rivers & 53 & $\mathrm{Y}$ & 0.535 \\
\hline N4 & Medium alkalinity rivers (medium size) & 35 & $\mathrm{Y}$ & 0.078 \\
\hline N5 & High alkalinity rivers (medium size) & 19 & & 0.334 \\
\hline N6 & Large lowland rivers & 75 & & 0.363 \\
\hline \multicolumn{5}{|c|}{ Southern rivers } \\
\hline $\mathrm{S} 1$ & Naturally acidic areas & 13 & $\mathrm{Y}$ & 0.002 \\
\hline S2 & Shallow rivers very close to source & 9 & & 0.388 \\
\hline S3 & Shallow rivers close to the source & 17 & $\mathrm{Y}$ & 0.153 \\
\hline S4 & Shallow rivers far from the source & 33 & Y & 0.201 \\
\hline S5 & Deeper rivers & 17 & & 0.514 \\
\hline \multicolumn{5}{|c|}{ Southern temporary rivers } \\
\hline $\mathrm{T} 1$ & High discharge upland rivers & 11 & & 0.373 \\
\hline $\mathrm{T} 2$ & Low discharge upland rivers & 23 & Y & 0.270 \\
\hline $\mathrm{T} 3$ & Small temporary rivers in the lowlands & 15 & $\mathrm{Y}$ & 0.579 \\
\hline $\mathrm{T} 4$ & Medium temporary rivers in the lowlands & 7 & & 0.742 \\
\hline $\mathrm{T} 5$ & Large lowland temporary rivers & 9 & & 0.162 \\
\hline
\end{tabular}

A higher proportion of river types have a good correlation $\left(r^{2}>0.2\right)$ with the nutrient gradient in the LINKTREE typology than in the national typology, although this tends to occur in any typology that has more types. The clustering of reference conditions is also better in the LINKTREE typology than in the national typology, and reference sites tend to be found more consistently at the lowest nutrient status within the river type (Fig. 3a and b). This is supported by the better separation of reference conditions in the LINKTREE typology compared to the national typology in the bar charts (Figs. 4 and 5).

Both the LINKTREE and national typologies indicate a distinct difference between the Northern and Southern Regions. However, beyond this there were large differences between the typologies. LINKTREE separated permanent from temporary rivers, and mountainous regions from lowland regions. The early separation of mountainous rivers in the analysis is probably due to the dominance of bryophytes and lack of vascular plants at these sites. Although the LINKTREE typology is discrete (not probabilistic) it still allows different river types within a small geographical area, based on features such as depth and distance from source, whereas the national typology was designed to cover large contiguous geographical regions.

The correlation of the metric EQR with the pressure gradient tended to be higher within the LINKTREE river types than within the national typology, e.g. types N2, N3, S5, T3 and T4 had $r^{2}$ values between 0.513 and 0.742 (Fig. 3a and b). Again, Type A (acidic) rivers had a poor correlation with the pressure gradient, although all reference sites had higher metric values than impacted sites. Similarly in the mildly acidic rivers of $\mathrm{S} 1(\mathrm{pH}<6.9)$ there was a poor correlation of EQR with the pressure gradient. This is probably due to the poor response of macrophytes to nutrient enrichment in acidic rivers as well as less severe impacts in these river types.

The metric site scores for impacted sites should be lower (lower quality) than for reference sites. $81 \%$ of impacted sites have a metric score lower than their reference condition in the LINKTREE typology, whereas the national typology performs worse, with $77 \%$ of impacted sites scoring lower than the reference condition. Also, mean metric site scores for impacted sites are lower than mean reference metric scores in each river type of the LINKTREE typology (Fig. 5), but not the national typology (Fig. 4). In the LINKTREE typology river types A, N1-N4, N6, S3, S4, T2 and T3 have significantly different mean reference and impacted site scores (Fig. 5). However, as with the national typology, there is not a significant difference between mean reference and impacted metric scores for many river types. The lack of separation may be due to low levels of impact at some sites, particularly in river type $\mathrm{M}$ (mountainous) (Fig. 3a).

\section{Species typical of Northern, Southern and Mountainous river types}

The National and LINKTREE typologies had similar frequencies of indicator species. For example, $O$. crocata, Carex elata and $P$. hydropiper were the three most frequent species in both typologies at reference condition in northern regions (all present at $>$ $60 \%$ of reference sites). O. crocata, L. salicaria and Lunularia cruciata were the three most frequent species in both typologies in southern region reference sites (all present at $>53 \%$ of reference sites). Mountainous regions were slightly different in their most common indicator species, although the top two most frequent reference indicators in both typologies were C. elata and Galium broteroanum (both present at $>80 \%$ of reference sites).

Many of the frequent species at reference sites were also frequent at impacted sites. For example the $O$. crocata and $P$. hydropiper were the two most common indicator species in the impacted sites of the north (both typologies) (>71\% frequency). $O$. crocata and $L$. salicaria were within the three most common species at impacted sites in the south ( $>69 \%$ frequency). This suggests that at impacted and reference sites, the common species vary little. Also, in indices that use ubiquitous species, the cover weightings of these species may obscure the impact response signal given by the rarer indicators.

The number of species that are unique at either impact of reference sites was also examined (Table 5). In mountainous, northern and southern rivers there are more species unique to impacted conditions than unique to reference conditions. This could be because unimpacted reference sites have less community variation than sites which are subject to a variety of different impacts. Also, it suggests that there is more likely to be an occurrence of new species associated with an impact rather than a loss of 'reference' species. The high number of unique species at reference condition in mountainous regions was probably due to the high number of reference sites and the low number of impacted sites within this river type. 
Table 5

Number of indicator species found at reference sites, but not impacted sites (and vice versa) within mountainous northern and southern regions of Portugal.

\begin{tabular}{llcr}
\hline & Mountainous & North & South \\
\hline Expert typology & 12 & & \\
$\quad$ Reference & 19 & 19 & 6 \\
Impacted & & & 13 \\
LINKTREE typology & 11 & 1 & \\
$\quad$ Reference & 19 & 18 & 5 \\
$\quad$ Impacted & & & 20 \\
\hline
\end{tabular}

\section{Discussion}

Despite being important structural and functional aspects of river ecology, aquatic macrophytes are usually given less priority in biological monitoring than invertebrates or fish. Simple, cheap and informative methods of aquatic macrophyte monitoring are required for the WFD. A metric was developed in this study that uses simple cover categories, a discrete and intuitively sensible typology, and 105 easily identifiable species. This metric was developed from the species change gradient within a data set (first axis in a DCA).

Often in developing biological metrics there is a failure to invest sufficiently in supporting chemical sampling and analysis, either because the researchers have more interest in the ecological field work, due to the cost of chemical sampling, or because the chemical and biological monitoring is not coordinated to produce co-supporting information. In this study the chemical analyses were particularly insensitive so it was considered inappropriate to use a metric calibrated against the chemistry data.

Although the species scores represent the main species change gradient, the high correlation of the metric with the combined nutrient gradient $\left(r^{2}=0.602\right)$ and similarities between species scores and MTR scores, suggests that the metric predominantly represents nutrient enrichment. However, there were species scores which differed from that expected from the MTR trophic metric.
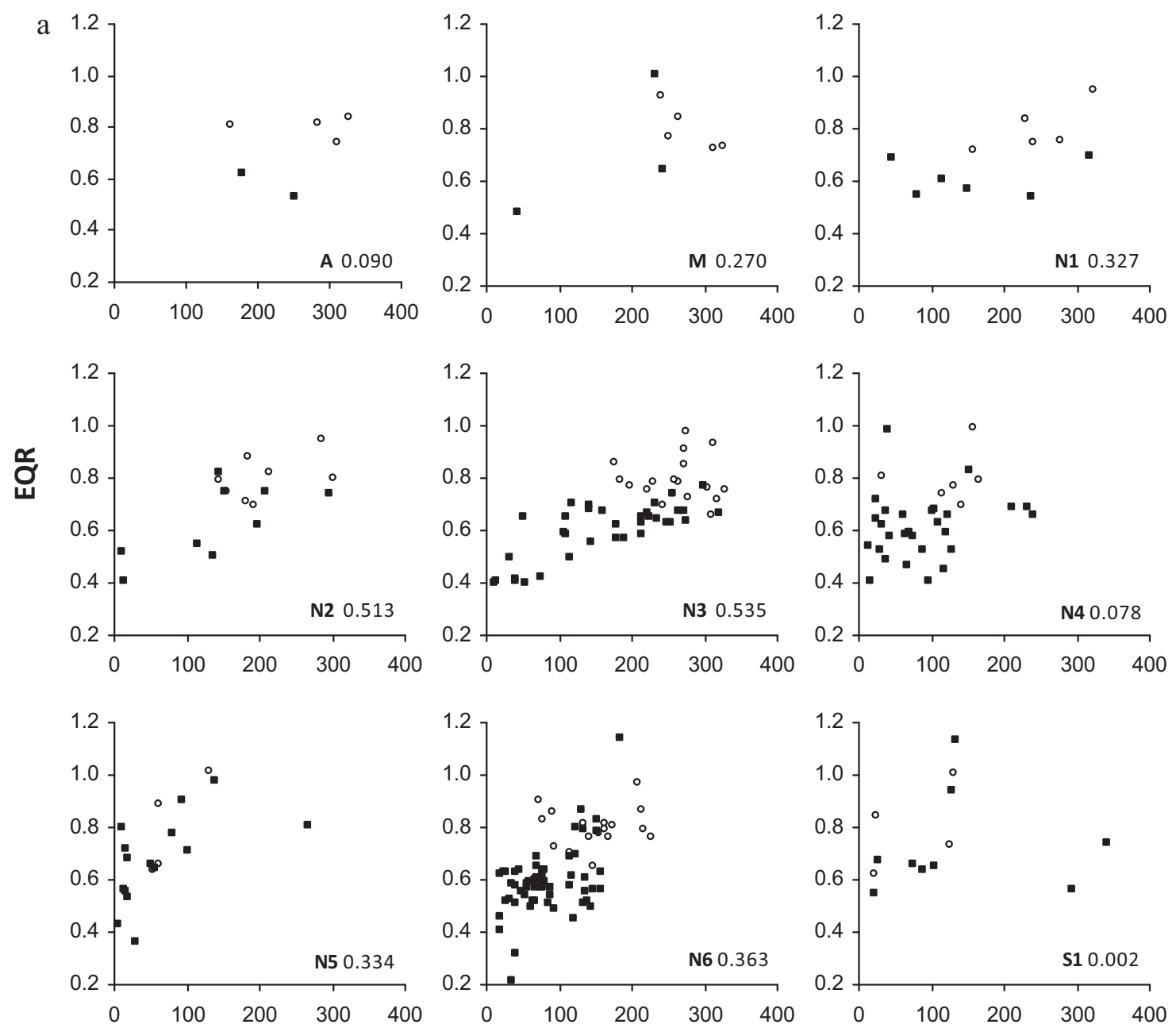

Nutrient gradient from PCA (rank)

Fig. 3. (a) Ecological Quality Ratio (EQR) of sites surveyed within river types within the LINKTREE typology, for Northern Portugal (and type S1), plotted against a nutrient gradient constructed from the 1st PCA axis of total nitrogen concentration, nitrate concentration, and impermeable surface area in the catchment. The $x$-axis is the rank nutrient gradient and the $y$-axis is the EQR value. The letter within each chart indicates the river type, and is followed by the $r^{2}$ value. Impacted sites are indicated as closed circles, reference sites as open circles. (b) Ecological Quality Ratio (EQR) of sites surveyed within river types within the LINKTREE typology, for Southern Portugal (excluding type S1), plotted against a nutrient gradient constructed from the 1st PCA axis of total nitrogen concentration, nitrate concentration, and impermeable surface area in the catchment. The $x$-axis is the rank nutrient gradient and the $y$-axis is the EQR value. The letter within each chart indicates the river type, and is followed by the $r^{2}$ value. Impacted sites are indicated as closed circles, reference sites as open circles. 

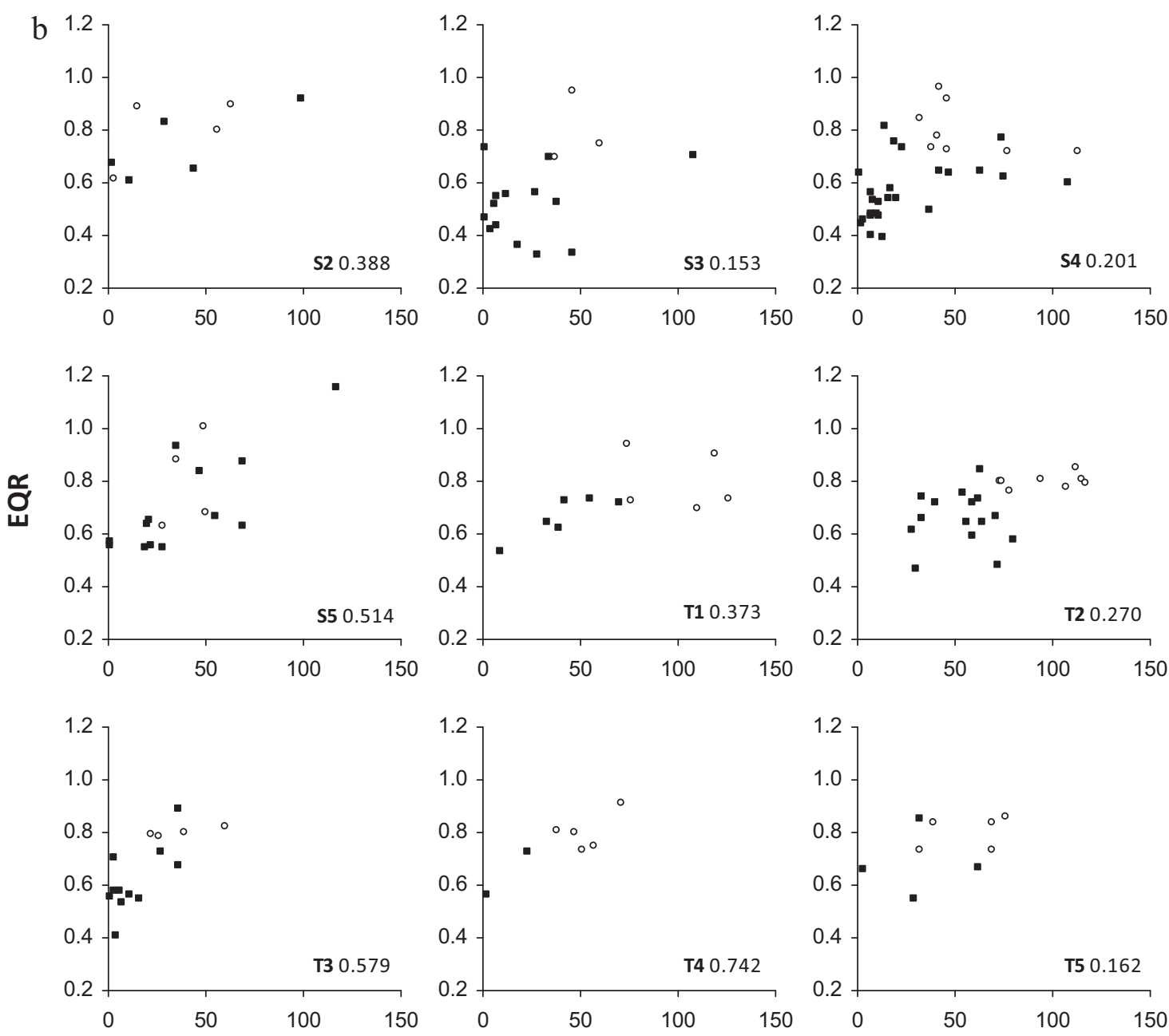

\section{Nutrient gradient from PCA (rank)}

Fig. 3. (Continued.)

Some of this can be explained by differences in the species niche between temperate and Mediterranean regions. For example, $C$. fragilis (a submerged macrophyte) has a wide ecological range but usually has an oligotrophic niche. In Mediterranean regions it may be pushed into more mesotrophic lowlands due to desiccation in oligotrophic rivers (possibly because summer flows in many rivers are dependent on effluent input). Similarly the submerged $C$. hamulata is associated with oligotrophic conditions in the UK and Netherlands, but in this study, as well as in Southern Germany and France (Schneider, 2007) has a greater ecological range often having a mesotrophic species score. P. australis, despite being ubiquitous, had a score associated with lowland conditions, though this may be due to its higher abundance in the channel in lowland rivers with open canopies, fine sediment deposits and often dry river beds.

In many upland areas acidity can be the over-riding factor controlling macrophyte community change (Robach et al., 1996) and thus the species scores may be more strongly associated with acidity in these regions. This limitation of macrophyte community change by factors other than trophic status (Barendregt and Bio, 2003) was the major criticism of current macrophyte metrics by Demars and Edwards (2009). However, the benefit of the DCA approach is that, although overall it was well correlated with nutrient enrichment, the species scores represent the main gradient in community change and not specifically trophic status.
The correlation of the metric with hydrological and hydromorphological impacts was unexpectedly low. It was probably due to the data being categorical rather than continuous. Analysis with more precise quantitative hydromorphological data should be attempted in the future. Also, the exclusion of some MTR scoring species, e.g. N. lutea, Cinclidotis and Saggitaria sagitifolia, was due to their rarity in the survey and not their absence in Portugal so future surveys should target such species to enable scores to be assigned.

With the exception of acidic rivers, the metric response to nutrient enrichment and separation of reference and impacted sites was generally good in northern Portugal. Temporary rivers in the south (the low discharge T2 rivers, and the large temporary rivers of T5) as well as the shallow rivers away from the source $(S 3, S 4)$ had poorer correlations between the metric and the nutrient pressure. This is likely to be due to the lower number of indicator species in drier rivers (Dodkins et al., 2011), and indicator species having a weaker association with the water column (i.e. submerged species were rare in southern rivers). The larger lowland rivers of the south (S5, T5) also had a poor separation of reference and impacted sites.

A further cause of the low sensitivity of the metric in the larger lowland rivers may be due to Weighted Averaging (WA). Reciprocal Averaging (RA) was used instead of WA to calculate species scores, and therefore the species scores are likely to be more robust than in WA, i.e. in WA species that occur at few sites can have poorly 


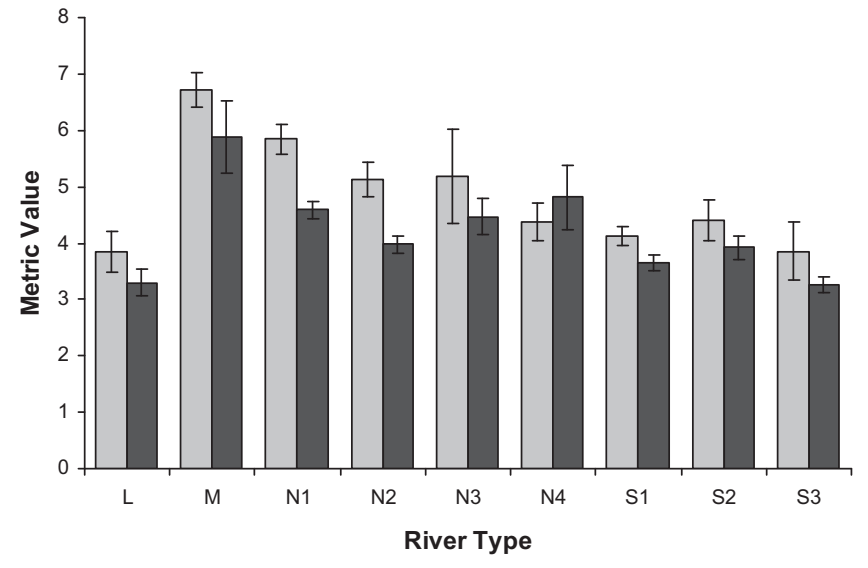

Fig. 4. Mean biological metric values at reference condition metric value (dark bar) compared to impacted sites (light bar) with 95\% confidence intervals (lines), for each river type within the national typology. High metric values infer high quality. River types are described in Table 1.

estimated optima, whereas RA is an iterative procedure based on species co-occurrence and therefore calculated from the whole data structure. Also there is no dependence on the accuracy or the time period of chemical monitoring data within RA, since it does not use chemical data for calibration, but instead represents the main gradient in community change. However, WA was used to calculate the site metric scores, and thus the EQR.

In lowland rivers which already have moderate concentrations of nutrients, the main ecological changes with nutrient enrichment are likely to be a loss of rare sensitive species and increases of abundance in species that may already be dominant (even at reference condition). Due to the WA score already being determined by the score of the more abundant species, neither of these ecological changes is likely to have much effect. This (as well as natural variation caused by differences in small scale physical habitat) may be why abundance weightings had little effect in the early development of both CBAS (Dodkins, 2005) and LEAFPACS (Willby, personal communication).

Indicator weightings have previously been used in methods such as the Trophic Diatom Index (Kelly, 1998) and CBAS (Dodkins et al., 2005a) in an attempt to assign more importance to good indicators that have low abundance. However, both of these methods

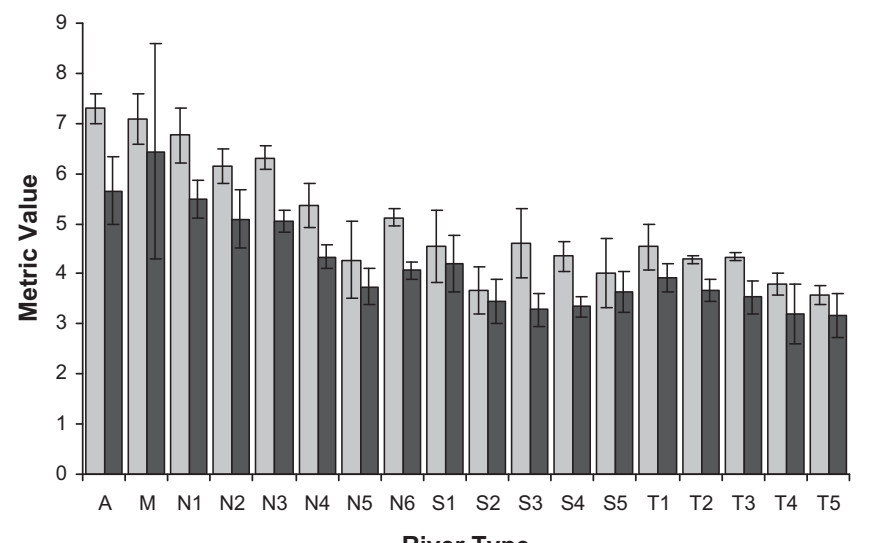

Fig. 5. Mean biological metric values at reference condition metric value (dark bar) compared to impacted sites (light bar) with $95 \%$ confidence intervals (lines), for each river type within the LINKTREE typology. High metric values infer high quality. River types are described in Table 4 later dropped the use of indicator weightings (Dodkins, 2005; Kelly et al., 2008) as they had little effect on the final scores. It is likely that the abundance of more sensitive species is limited by small scale habitat availability and therefore there can be a weak abundance response to nutrient increases whereas species associated with nutrient enrichment (e.g. E. canadensis, Lagarosiphon major) can often colonise large areas rapidly with less limitations from substrate availability and thus show a more pronounced abundance response to nutrient enrichment (e.g. Dodkins, 2003). Thus, using the same abundance categories for all species may obscure the trophic response signal. A simple and effective alternative is a method used by Schaumburg et al. (2004) and Willby et al. (2009) whereby a site score is calculated using separate averages for sensitive (and usually rarer) species, tolerant species, and species with a neutral response to nutrient impacts. Such metrics are likely to have a more pronounced response to the loss of sensitive species in lowland habitats since the score of sensitive species is not smothered by the score of dominant, more tolerant, species.

This metric in this study is similar to the Eastern Canadian Diatom Index (IDEC) (Lavoie et al., 2006), except that Lavoie et al. measured the distance between the monitoring site and the reference condition rather than assigning a score to species, and that CA was used. The advantage of assigning a score to species is that the reference conditions can be improved or changed without affecting the initial monitoring site score calculation. It also enables the species scores to be independently evaluated based on expert judgment, without confusion over whether the reference sites or the species scores are the source of inaccuracy. This metric also shares some similarities with the German reference index (RI) (Schaumburg et al., 2004) since, although an impact is presumed as the major cause of species change, the method calculates species scores without direct reference to a specific pressure gradient.

Although the national typology and LINKTREE typology differed, they both indicated the large ecological difference between rivers of north and south Portugal. The LINKTREE analysis achieves what Dodkins et al. (2005b) attempted to do, in producing a typology that optimally separates biological communities whilst simultaneously selecting environmental variables and divisions along these environmental gradients at which the communities are maximally separated. The approach is similar to Multivariate Regression Trees developed by De'ath (2002). Unlike Discriminant Function Analysis (DFA) it does not require a linear separation along an environmental gradient (the same environmental factor can be used at different levels in the hierarchical classification) and LINKTREE is not probabilistic, so a discrete typology which is easy to interpret is produced. The LINKTREE typology performed much better than the national typology, however both indicated the difficulties of developing a macrophyte metric in the drier southern rivers.

Methods of aquatic macrophyte assessment in Mediterranean rivers, particularly temporary rivers, may require different approaches to those used in temperate climates. Low numbers of aquatic species are likely to be limiting the performance of the metric in temporary rivers. The large proportion of terrestrial species in temporary rivers (up to $50 \%$ of in the Guadiana river channel (Ferreira et al., 2001)) may be a justification for including nonaquatic species in metrics for Mediterranean rivers, i.e. species considered 'riparian species' in temperate climates are often found in the dry river channel of Mediterranean rivers. Since drying in such rivers is a "continuous and gradual process" (Ferreira et al., 2001 ) the succession of these species could be a good indicator of the hydrological regime. Non-aquatic channel species may also be indicative of the nutrient status of sediment deposited in the river channel prior to drying. Increasing the number of indicator species could also be achieved by combining diatoms and macrophytes within a single index (e.g. Dodkins et al., 2011). 
RA for calculating species scores is recommended when chemistry data is poor or inconsistent, though the metric response to human impacts always needs to be validated. There is scope for improving WA methods for calculating site metric scores. Functional metrics could also be included in a multi-metric index to enable a more comprehensive and interpretable response to a variety of impacts.

\section{Conclusions}

The national and the LINKTREE typology both support the view that aquatic macrophyte communities in the north and south of Portugal are distinct, probably due to the Mediterranean (drier and spateyer rivers) of the south. Southern rivers have fewer species and often less pronounced community responses to perturbation.

Despite the metric not being specifically designed to measure trophic status, it had a good correlation with a nutrient gradient. However, it had much lower correlations with the nutrient gradient in acidic rivers and the drier temporary rivers of the south. The poor response of macrophyte communities to nutrient enrichment in acidic rivers is already known to occur. The poor response in the larger drier rivers of the south is likely due to low species numbers, abundance of many species being dependent on the variability in small scale physical habitat, and simple WA calculations not responding sufficiently to increases in cover of dominant species and loss of rare species.

An aquatic macrophyte metric for Mediterranean regions must aim to maximise the information available from the plants; possibly including terrestrial species in the channel, additional functional metrics (e.g. vegetation structure, species diversity), and improving how abundance is used, e.g. separating sensitive and tolerant species prior to WA calculations. Further investigation into assessing ecological changes in temporary rivers is also recommended.

\section{Acknowledgements}

Thanks to the Water Institute, Portugal (INAG, IP) for supplying both data and funding and the Foundation for Science and Technology who supported Francisca Aguiar with post-doctoral grant (SFRH/BPD/29333/2006). We are indebted to Teresa Vasconcellos for vascular flora identification, Cecília Sérgio and Inês Silva for bryophyte identification, Paulo Pinheiro for GIS support, and Luis Lopes for field sampling assistance. Special thanks go to Pedro Segurado for helpful comments, and to Joana Patricia who conducted a preliminary review and gave limitless encouragement. Thanks also to the two anonymous reviewers.

\section{Appendix A.}

Aquaticity (link to water) categorisation of macrophytes developed by Chauvin (Birk et al., 2007). Only species with Aquaticity of five or less were included in this study.

\begin{tabular}{ll}
\hline 1 & $\begin{array}{l}\text { Exclusively aquatic species (or mainly aquatic in regular conditions). } \\
\text { Aquatic taxon with common terrestrial forms or truly amphibious } \\
\text { (common aquatic forms as well as terrestrial forms). }\end{array}$ \\
3 & $\begin{array}{l}\text { Supra-aquatic bryophyta and lichens. Commonly submersed for part } \\
\text { of the hydrological cycle. }\end{array}$ \\
4 & $\begin{array}{l}\text { Helophytes or amphiphytes. Erect forms with base commonly inside } \\
\text { water. }\end{array}$ \\
5 & $\begin{array}{l}\text { Hygrophylous taxa. Possibly submersed (at least the base) a part of the } \\
\text { year. }\end{array}$ \\
6 & $\begin{array}{l}\text { Bank, wood, grasslands or ruderal herbaceous species. May be found in } \\
\text { water accidentally or in high flow conditions. }\end{array}$ \\
7 & $\begin{array}{l}\text { Woody riparian species. May be flooded temporarily. } \\
\text { Brackish water or salt-marsh species. }\end{array}$ \\
\hline
\end{tabular}

\section{Appendix B.}

Species scores for the 105 species in the DCA macrophyte metric. Species found at higher ecological status have higher scores.

\begin{tabular}{|c|c|c|c|}
\hline Species & Score & Species & Score \\
\hline Philonotis fontana & 10 & Anogramma leptophylla & 4 \\
\hline Centaurea nigra ssp. rivularis & 9 & Callitriche cribrosa & 4 \\
\hline Scapania undulata & 9 & Callitriche stagnalis & 4 \\
\hline Sphagnum spp. & 9 & Carex paniculata ssp. lusitanica & 4 \\
\hline Euphorbia dulcis & 8 & Carex pendula & 4 \\
\hline Juncus bulbosus & 8 & Carex remota & 4 \\
\hline Jungermannia spp. & 8 & Cyperus eragrostis & 4 \\
\hline Molinia caerulea & 8 & Eleocharis multicaulis & 4 \\
\hline Racometrium spp. & 8 & Eleocharis palustris & 4 \\
\hline Ranunculus tripartitus & 8 & Juncus bufonius & 4 \\
\hline Brachythecium rutabulum & 7 & Leersia oryzoides & 4 \\
\hline Carex elata ssp. reuterana & 7 & Lemna minor & 4 \\
\hline Chiloscyphus polyanthos & 7 & Lunularia cruciata & 4 \\
\hline Fontinalis squamosa & 7 & Lythrum salicaria & 4 \\
\hline Galium broteroanum & 7 & Mentha pulegium & 4 \\
\hline Hygrohypnum ochraceum & 7 & Polygonum hydropiper & 4 \\
\hline Marchantia polymorpha & 7 & Ranunculus bulbosus & 4 \\
\hline Schistidium rivulare & 7 & Ranunculus peltatus & 4 \\
\hline Brachythecium rivulare & 6 & Alisma plantago-aquatica & 3 \\
\hline Calliergonella cuspidata & 6 & Apium nodiflorum & 3 \\
\hline Carex laevigata & 6 & Azolla filiculoides & 3 \\
\hline Cirsium palustre & 6 & Callitriche brutia & 3 \\
\hline Dryopteris filix-mas & 6 & Callitriche hamulata & 3 \\
\hline Eleogiton fluitans & 6 & Eichhornia crassipes & 3 \\
\hline Fontinalis antipyretica & 6 & Equisetum palustre & 3 \\
\hline Juncus heterophyllus & 6 & Isoetes histrix & 3 \\
\hline Myosotis debilis & 6 & Juncus hybridus & 3 \\
\hline Myosotis lusitanica & 6 & Mentha aquatica & 3 \\
\hline Myriophyllum alterniflorum & 6 & Myriophyllum aquaticum & 3 \\
\hline Polystichum setiferum & 6 & Paspalum dilatatum & 3 \\
\hline Potamogeton natans & 6 & Potamogeton nodosus & 3 \\
\hline Potamogeton polygonifolius & 6 & Pulicaria paludosa & 3 \\
\hline Ranunculus flammula & 6 & Ranunculus penicillatus & 3 \\
\hline Rhynchostegium riparioides & 6 & Sparganium erectum & 3 \\
\hline Scutellaria minor & 6 & Typha dominguensis & 3 \\
\hline Stellaria alsine & 6 & Typha latifolia & 3 \\
\hline Thamnobryum alopecurum & 6 & Veronica beccabunga & 3 \\
\hline Amblystegium riparium & 5 & Alisma lanceolatum & 2 \\
\hline Callitriche obtusangula & 5 & Chara fragilis & 2 \\
\hline Eupatorium cannabinum & 5 & Epilobium hirsutum & 2 \\
\hline Glyceria fluitans ssp. declinata & 5 & Lemna gibba & 2 \\
\hline Iris pseudacorus & 5 & Myriophyllum spicatum & 2 \\
\hline Juncus effusus & 5 & Paspalum distichum & 2 \\
\hline Lemanea sp. & 5 & Polygonum amphibium & 2 \\
\hline Ludwigia palustris & 5 & Potamogeton crispus & 2 \\
\hline Lycopus europaeus & 5 & Rorippa nasturtium-aquaticum & 2 \\
\hline Lysimachia vulgaris & 5 & Schoenoplectus lacustris & 2 \\
\hline Myosotis laxa ssp. caespitosa & 5 & Veronica anagallis-aquatica & 2 \\
\hline Oenanthe crocata & 5 & Arundo donax & 1 \\
\hline Prunella vulgaris & 5 & Elodea canadensis & 1 \\
\hline Ranunculus trichophyllus & 5 & Phragmitis australis & 1 \\
\hline Saponaria officinalis & 5 & Potamogeton pusillus & 1 \\
\hline Scrophularia scorodonia & 5 & & \\
\hline
\end{tabular}

\section{Appendix C.}

Key for deciding which river type a site belongs based on LINKTREE analysis.

\begin{tabular}{|c|c|c|c|}
\hline \multirow[t]{2}{*}{1} & Is it a very high altitude site $(>850 \mathrm{~m})$ & Yes & Type $\mathbf{M}$ \\
\hline & & No & \\
\hline \multirow[t]{2}{*}{2} & Is it in a (naturally) highly acidic area $(\mathrm{pH}<=5.3$ ) & Yes & Type $\mathbf{A}$ \\
\hline & & No & 3 \\
\hline \multirow[t]{2}{*}{3} & Is it a Northern (latitude $>337,500$ ) or & North & 4 \\
\hline & Southern (latitude $<=337,500$ ) river & South & 8 \\
\hline \multicolumn{4}{|c|}{ Northern (temperate) Rivers } \\
\hline \multirow[t]{2}{*}{4} & Is it an upland site (altitude $>=700 \mathrm{~m}$ ) & Yes & Type N1 \\
\hline & & No & 5 \\
\hline 5 & Is it a small catchment (area $>180 \mathrm{~km}^{2}$ ) & Yes & 6 \\
\hline
\end{tabular}




\begin{tabular}{|c|c|c|c|}
\hline \multirow[b]{2}{*}{6} & \multirow{3}{*}{ Is the alkalinity (units): } & \multirow{2}{*}{$\begin{array}{l}\text { No } \\
<=20\end{array}$} & \multirow{2}{*}{$\begin{array}{l}\text { Type N6 } \\
7\end{array}$} \\
\hline & & & \\
\hline & & $>20-50$ & Type N4 \\
\hline & & $>50$ & Type N5 \\
\hline \multirow[t]{2}{*}{7} & $\begin{array}{l}\text { Is it a very northern } \\
\text { area? } \\
\text { (latitude }>=515000 \text { ) }\end{array}$ & Yes & Type $\mathbf{N 2}$ \\
\hline & & No & Type N3 \\
\hline \multicolumn{4}{|c|}{ Southern (Mediterranean) rivers } \\
\hline \multirow[t]{2}{*}{8} & $\begin{array}{l}\text { Is it a shallow river } \\
(<0.8 \mathrm{~m})\end{array}$ & Yes & 9 \\
\hline & & No & Type $\mathbf{S 5}$ \\
\hline 9 & $\begin{array}{l}\text { Is it in a (naturally) } \\
\text { acidic area ( } \mathrm{pH}<6.9)\end{array}$ & Yes & Type $\mathbf{S 1}$ \\
\hline \multirow[t]{2}{*}{10} & $\begin{array}{l}\text { Is the river very close } \\
\text { to the source }\end{array}$ & $\begin{array}{l}\text { No } \\
\text { (dist. from } \\
\text { source }<=6 \mathrm{~km} \text { ) }\end{array}$ & $\begin{array}{l}10 \\
\text { Type } \mathbf{S} 2\end{array}$ \\
\hline & & $\begin{array}{l}\text { (dist. from } \\
\text { source }>6 \mathrm{~km} \text { ) }\end{array}$ & 11 \\
\hline 11 & $\begin{array}{l}\text { Is the flow regime of } \\
\text { the river: }\end{array}$ & Permanent & 12 \\
\hline \multirow[t]{2}{*}{12} & $\begin{array}{l}\text { Is the site close to the } \\
\text { source }\end{array}$ & $\begin{array}{l}\text { Temporary } \\
\text { (dist. from source } \\
<16.3 \mathrm{~km} \text { ) }\end{array}$ & $\begin{array}{l}13 \\
\text { Type } \mathbf{S 3}\end{array}$ \\
\hline & Or far from the source & $\begin{array}{l}\text { (dist. from } \\
\text { source }>=16.2 \mathrm{~km} \text { ) }\end{array}$ & Type $\mathbf{S 4}$ \\
\hline \multicolumn{4}{|c|}{ Temporary southern rivers } \\
\hline \multirow[t]{2}{*}{13} & $\begin{array}{l}\text { Is it a large catchment } \\
\left(\text { area }>250 \mathrm{~km}^{2}\right)\end{array}$ & Yes & Type $\mathbf{T 5}$ \\
\hline & & No & 14 \\
\hline \multirow[t]{2}{*}{14} & $\begin{array}{l}\text { Is it a mid or upland } \\
\text { site (altitude }>110 \mathrm{~m} \text { ) }\end{array}$ & Yes & 15 \\
\hline & & No & 16 \\
\hline \multirow[t]{2}{*}{15} & $\begin{array}{l}\text { Is it a high discharge } \\
\text { river (>200 } \mathrm{mm} \\
\text { rainfall) }\end{array}$ & Yes & Type T1 \\
\hline & & No & Type $\mathbf{T 2}$ \\
\hline \multirow[t]{2}{*}{16} & $\begin{array}{l}\text { Is it a small catchment } \\
\text { area }\left(<75 \mathrm{~km}^{2}\right)\end{array}$ & Yes & Type $\mathbf{T 3}$ \\
\hline & & No & Type $\mathbf{T 4}$ \\
\hline
\end{tabular}

\section{References}

Aguiar, F., Ferreira, M.T., Albuquerque, A., Rodriguez-González, P., 2008. Tipologia ripícola de sistemas fluviais portugueses. Tecnologia da Água 3, 30-38.

Aguiar, F.C., Feio, M.J., Ferreira, M.T., 2011. Choosing the best method for stream bioassessment using macrophyte communities: indices and predictive models. Ecol. Indic. 11, 379-388.

Armitage, P.D., Moss, D., Wright, J.F., 1983. The performance of a new biological water quality score system based on macroinvertebrates over a wide range of polluted running-water sites. Water Res. 17, 333-347.

Barendregt, A., Bio, A.M.F., 2003. Relevant variables to predict macrophyte communities in running waters. Ecol. Model. 160, 205-217.

Bartram, J., Ballance, R., 1996. Water Quality Monitoring. Chapman and Hall, London.

Benzérci, J., 1973, L'analyse des données. Tome I: la taxinomie. Tome II: L'analyse des correspondances. Paris.

Birk, S., Willby, N., Chauvin, C., Coops, H., Denys, L., Galoux, D., Kolada A., Pall, K., Pardo, I., Pot, R., Stelzer, D., 2007. Report on the Central Baltic River GIG macrophyte intercalibration exercise, CIRCA http://circa.europa.eu/Public/irc/jrc/jrc_eewai/library?l=/milestone_reports/ milestone_reports_2007/rivers/cb_gig/june-07-v2_annexes/cbrivgig_june-07v2pdf_1/_EN_1.0_\&a=d.

Birk, S., 2011. WISER Deliverable D2.1-1: database on assessment methods for lakes, rivers, coastal and transitional waters in Europe. In: Water Bodies In Europe: Integrative Systems to assess Ecological status and Recovery (WISER). University of Duisburg-Essen, Germany.

Carbiener, R., Tremolieres, M., Mercier, J.L., Ortscheit, A., 1990. Aquatic macrophyte communities as bioindicators of eutrophication in calcareous oligosaprobe stream waters (Upper Rhine Plain, Alsace). Vegetatio 86, 71-88.

Carpenter, S.R., Lodge, D.M., 1986. Effects of submerged macrophytes on ecosystem processes. Aquat. Bot. 26, 341-370.

CEN, 2003. Water quality-guidance for the surveying of aquatic macrophytes in running waters. EN14184:2003. Comité Européen de Normalization.

Cheruvelil, K., Soranno, P.A., Serbin, R.D., 2000. Macroinvertebrates associated with submerged macrophytes: sample size and power to detect effects. Hydrobiologia 441, 133-139.

Clarke, K.R., Gorley, R.N., 2006. PRIMER v.6 User Manual/Tutorial. PRIMER-E Ltd., Plymouth.
Clesceri, L.S., Greenberg, A.E., Eaton, A.D., 1999. Standard Methods for the Examination of Water \& Wastewater, 20th ed. American Public Health Association, Washington, USA.

Collier, K.J., Champion, P.D., Croker, G.F., 1999. Patch- and reach-scale dynamics of a macrophyte-invertebrate system in a New Zealand lowland stream. Hydrobiologia 392, 89-97.

Council of the European Communities, 2000. Directive of the European Parliament and of the Council establishing a framework for Community action in the field of water policy. L327. Official Journal of the European Communities 43 . $1-73$.

Dawson, F.H., Newman, J.R., Gravelle, M.J., Rouen, K.J., Henville, P., 1999. Assessment of the Trophic Status of Rivers Using Macrophytes. Evaluation of the Mean Trophic Rank. Environment Agency, Bristol.

De'ath, G., 2002. Multivariate regression trees: a new technique for modelling species-environment relationships. Ecology 83, 1105-1117.

De Pauw, N., Vanhooren, G., 1983. Method for biological quality assessment of watercourses in Belgium. Hydrobiologia 100, 153-168.

Demars, B.O.L., Edwards, A.C., 2009. Distribution of aquatic macrophytes in contrasting river systems: a critique of compositional based assessment of water quality. Sci. Total Environ. 407, 975-990.

Den Hartog, C., 1982. Architecture of macrophyte-dominated aquatic communities. In: Symoens, J.J., Hooper, S.S., Compère, P. (Eds.), Architecture of Macrophytedominated Aquatic Communities. Royal Botanical Society of Belgium, Brussels, pp. 222-234.

Dodkins, I.R., 2003. Developing a macrophyte index of ecological status for Northern Ireland's rivers. PhD Thesis, University of Ulster, Coleraine.

Dodkins, I.R., 2005. NS-Share Technical Report: CBAS Development. NSSHARE, Northern Ireland Environment and Heritage Service, Belfast.

Dodkins, I.R., Rippey, B., 2008. Objectivity and confidence in ecological assessments of rivers and lakes. In: Heikkinen, E. (Ed.), Water Resource Research Progress. Nova Science Publishers, New York.

Dodkins, I.R., Rippey, B., Hale, P., 2005a. An application of canonical correspondence analysis for developing ecological quality assessment metrics for river macrophytes. Freshw. Biol. 50, 891-904.

Dodkins, I.R., Aguiar, F., Ferreira, M.T., 2011. Can Mediterranean river plants translate into quality assessment systems? Venturing into unexplored territories. In: Boon, P., Raven, P. (Eds.), River Conservation and Management. Joint Nature Conservation Committee, Peterborough.

Dodkins, I.R., Rippey, B.R.H.T., Harrington, T.J., Bradley, C., Ni Chathain, B., KellyQuinn, M., McGarrigle, M., Hodge, S., Trigg, D., 2005b. Developing an optimal river typology for biological elements within the Water Framework Directive. Water Res. 39, 3479-3486.

Ferreira, M.T., Albuquerque, A., Aguiar, F., Catarino, L.F., 2001. Seasonal and yearly variations of macrophytes in a southern Iberian river. Verh. Intern. Ver. Limnol. 27, 3833-3837.

Ferreira, M.T., Rodríguez-Gonzaález, P.M., Aguiar, F.C., Alburquerque, A., 2005 Assessing biotic integrity in Iberian rivers: development of a multimetric plant index. Ecol. Indic. 5, 137-149.

Fowler, J., Lou, C., Jarvis, P., 1998. Practical Statistics for Field Biology. John Wiley and Sons, Chichester.

Haury, J., 1996. Assessing functional typology involving water quality, physical features and macrophytes in a Normandy river. Hydrobiologia 340 , 43-49.

Haury, J., Peltre, M.-C., Trémolièrs, M., Barbe, J., Thiébaut, G., Bernez, I., Daniel, H., Chaternet, P., Haan-Archipof, G., Muller, S., Dutartre, A., Laplace-Treyture, C., Cazaubon, A., Lambert-Servien, E., 2006. A new method to assess water trophy and organic pollution-the Macrophyte Biological Index for Rivers (IBMR): its application to different types of river and pollution. Hydrobiologia 570, 153-158.

Hawkes, H.A., 1998. Origin and development of the biological monitoring working party score system. Water Res. 32, 964-968.

Hill, M.O., Gauch, H.G., 1980. Detrended Correspondence Analysis: an improved ordination technique. Vegetatio 42, 47-58.

Holmes, N.T.H., Newman, J.R., Dawson, F.H., Chadd, S., Rouen, K.J., Sharp, L., 1999 Mean Trophic Rank: a user's manual. R\&D Technical Report. Environment Agency, Bristol.

INAG, 2008a. Manual para a avaliação biológica da qualidade da água em sistemas fluviais segundo a Directiva Quadro da Água. Protocolo de amostragem e análise para os macrófitos. Ministério do Ambiente, do Ordenamento do Território e do Desenvolvimento Regional, Instituto da Água IP, Lisboa, $18 \mathrm{pp}$.

INAG, 2008b. Tipologia de Rios em Portugal Continental no âmbito da Implementação da Directiva Quadro da Água. I. Caracterização abiótica. http://dqa.inag.pt/dqa2002/port/implementa/Manuais.html. Ministério do Ambiente, do Ordenamento do Território e do Desenvolvimento Regional, Instituto da Água IP, Lisbon, 32 pp.

Kelly, M.G., 1998. Use of the trophic diatom index to monitor eutrophication in rivers. Water Res. 32, 236-242.

Kelly, M.G., Juggins, S., Guthrie, R., Pritchard, S., Jamieson, B.J., Rippey, B., Hirst, H., Yallop, M.L., 2008. Assessment of ecological status in UK rivers using diatoms. Freshw. Biol. 53, 403-422.

Lavoie, I., Campeau, S., Grenier, M., Dillon, P.J., 2006. A diatom-based index for the biological assessment of eastern Canadian rivers: an application of correspondence analysis (CA). Can. J. Fish. Aquat. Sci. 63, 1793-1811.

Lenoir, A., Coste, M., 1996. Development of a practical diatom index of overall water quality applicable to the French National Water Board network. In: Whitton, 
B.A, Rott, E. (Eds.), Use of Algae for Monitoring Rivers II. Institut für Botanik, Universität Innsbruck, pp. 29-43.

Marshall, E.J.P., Westlake, D.F., 1978. Recent studies on the role of aquatic macrophytes in their ecosystem. In: Proceedings of the EWRS 5th Symposium on Aquatic Weeds, pp. 183-188.

Melzer, A., 1999. Aquatic macrophytes as tools for lake management. Hydrobiologia 395/396, 181-190.

Pall, K., Mayerhofer, V., 2008. Leitfaden zur Erhebung biologischer Qualitätselemente, Teil A4- Makrophyten. Bundesministerium für Land- und Forstwirtschaft, Umwelt und Wasserwirtschaft (Hrsg.), 60 pp.

Pantle, R., Buck, H., 1955. Die biologische Uberwachung der Gewässer und die Darstellung der Ergebnisse. Gas Wasserfach 96, 604.

Persoone, G., De Pauw, N., 1979. Systems of biological indicators for water quality assessment. In: Ravera, O. (Ed.), Biological Aspects of Freshwater Pollution. Pergamon Press, Oxford, pp. 39-75.

Raven, P.J., Holmes, N.T.H., Dawson, F.H., Fox, P.J.A., Everard, M., Fozzard, I.R., Rouen, K.J., 1998. River Habitat Quality: the physical character of rivers and streams in the UK and Isle of Man. Environment Agency, Bristol.

Reiser, H., Kutiel, H., 2010. Rainfall uncertainty in the Mediterranean: dryness distribution. Theor. Appl. Clim. 100, 123-135.

Reynoldson, T.B., Bailey, R.C., Day, K.E., Norris, R.H., 1995. Biological guidelines for freshwater sediment based on BEnthic Assessment of SedimenT (the BEAST) using a multivariate approach for predicting biological state. Aust. J. Ecol. 20, 198-219.

Robach, F., Thiebaut, G., Tremolieres, M., Muller, S., 1996. A reference system for continental running waters: plant communities as bioindicators of increasing eutrophication in alkaline and acidic waters of north-east France. Hydrobiologia 340, 67-76.

Schaumburg, J., Schranz, C., Foerster, J., Gutowski, A., Hofmann, G., Meilinger, P. Schneider, S., 2004. Ecological classification of macrophytes and phytobenthos for rivers in Germany according to the Water Framework Directive. Limnologica 34, 283-301.

Schneider, S., 2007. Macrophyte trophic indicator values from a European perspective. Limnologica 37, 281-289.

Sokal, R.R., Rohlf, F.J., 1995. Biometry: the principles and practise of statistics in biological research, 3rd ed. W.H. Freeman, New York.

Stoddard, J.L., Larsen, D.P., Hawkins, C.P., Johnson, R.K., Norris, R.H., 2006. Setting expectations for the ecological condition of streams: the concept of the reference condition. Freshwater Bioassessment 16, 1267-1276.

Suarez, L., Mellado, A., Sanchez-Montoya, M., Vidal-Abarca, R., 2005. Propuesta de un indice de macrofitos (IM) para evaluar la calidad ecologica de los rios de la cuenca del Segura. Limnetica 24, 305-318.

Szoszkiewicz, K., Zbierska, J., Jusik, S., Zgoła, T., 2008. Metoda oceny rzek oparta na makrofitach realizowana w Polsce na potrzeby Ramowej Dyrektywy Wodnej. Wiad. Mel. i Łąk. 4, 163-165.

Szoszkiewicz, K., Ferreira, T., Korte, T., Baattrup-Perdersen, A., Davy-Bowker, J., O'Hare, M., 2006. European river plant communities: the importance of organic pollution and the usefulness of existing macrophyte metrics. Hydrobiologia 566, 211-234.

ter Braak, C.J.F., Looman, C.W.N., 1986. Weighted averaging, logistic regression and the Guassian response model. Vegetatio 65, 3-11.

ter Braak, C.J.F., Smilauer, P., 2002. CANOCO version 4.5. Microcomputer Power. Ithica, NY, USA.

Wilby, R.L., Cranston, L.E., Darby, E.J., 1998. Factors governing macrophyte status in Hampshire chalkstreams: implications for catchment management. J. Chartered Inst. Water Environ. Manage. 12, 179-187.

Willby, N.J., Pitt, J., Phillips, G., 2009. The ecological classification of UK rivers using aquatic macrophytes. Environment Agency, Bristol.

Wright, J.F., 1995. Development and use of a system for predicting the macroinvertebrate fauna of flowing waters. Aust. J. Ecol. 20, 181-197. 